\title{
Cultural Practices and Traditional Beliefs as Impediments to the Enjoyment of Women's Rights in Nigeria
}

\author{
Agbonika John Musa Alewo ${ }^{1} \&$ Matthew Adefi Olong ${ }^{1}$ \\ ${ }^{1}$ Faculty of Law, Kogi State University, Anyigba, Nigeria \\ Correspondence: Matthew Adefi Olong, Faculty of Law, Kogi State University, Anyigba, Nigeria. Tel: \\ 803-406-9932. E-mail: adefiolong@yahoo.com
}

\author{
Received: April 2, 2012 Accepted: May 3, 2012 Online Published: October 26, 2012 \\ doi:10.5539/ilr.v1n1p134 URL: http://dx.doi.org/10.5539/ilr.v1n1p134
}

\begin{abstract}
The article considered the growing interest in human rights as it is affected by cultural practices in relation to women in different communities in Nigeria. It pointed out some of the cultural practices that bedevil the womenfolk, rendering them virtually impossible to realize their full potentials as human beings, in the light of the third millennium. The article analyzed some culture and traditional beliefs such as inheritance of men by their deceased husband's relations, windows succession rights, bride price and dowry, child and forced marriages. The article concluded by making suggestions that would enhance the enjoyment of the rights of women in Nigeria in the third millennium.
\end{abstract}

Keywords: cultural practices, rights, women's rights, impediments, customary practices

\section{Introduction}

The growing interest in human rights especially as it is affected by cultural or customary practices in relation to the rights of women in different communities in Nigeria has no doubt increased. Its prevalence has necessitated human rights activists/groups to discuss at various fora why, cultural practices are often cited as justification for denying women a wide range of basic rights and the seemingly way forward. In the words of Higgins (1990: 89), feminists note that the culture and religion relation are often cited as justifications for denying women a wide range of basic right.

According to Ngangah (1998: 7) culture being a way of life of a people is usually difficult but not impossible to change. In Nigeria, it has been observed that women in many communities are discriminated against on a daily basis under the excuse of culture, or custom. Culture prohibits a number of things among certain groups of the society (Omoso, 2009). These are things people claim women should not do, yet these things, if culture allowed them, would have helped a lot of women toward being self-reliant and actualized.

In discussing the impediments to the enjoyment of the rights of women, the discriminatory practices embarked upon by the male dominated society in Nigeria comes to fore. Thus, since there is hardly any talk about the impediments to the rights of men, it follows that the cultural impediments to be discussed hereunder are impediments initiated, supported and enforced mainly by the men folk albeit with support from some women, in enslaving the women.

It is pertinent to note that since the attainment of Nigeria's independence, little or no attention has been paid to the "women" in the laws so far made. The Constitution of Nigeria (1999: as amended, 2011) and the previous constitutions of Nigeria merely make general reference to the people of Nigeria as citizens without singling out the "women". The only provision that recognizes women is the reference to the citizenship of foreigners married to Nigerians. The Criminal Code Act of the Federation of Nigeria is one of the very few laws that recognize the need to specifically protect women's rights as it contains provisions relating to infanticide, indecent assaults on women, brothels, prostitution and unnatural offences.

It appears, therefore, that women are not given adequate protection by Nigerian laws, as the protection available remain minimal compared to those in developed and advanced nations. It should, however, be grasped from the onset that Nigeria is signatory to many international, regional and sub-regional human rights instruments that protect and guarantee the rights of women. This paper seeks to explore same and proffer solutions for the enhancement of the rights of women in Nigeria. 


\section{Conceptual Clarifications}

\subsection{Woman}

The word "woman," has been defined to mean "an adult female of the human race: a wife, a mistress... the female sex." Woman, in sum, has also been said to be an adult female human being, physically weaker than the man, exhibiting feminine characteristics quite distinctive from the opposite sex that is, man. The Women's Rights Protocol defines "Woman," to mean "persons of female gender, including girls." There is a clear distinction between a woman and a man who is said to be a grown-up human male. Basically, three categories of women, namely, the married, unmarried and the widowed are often discernable in trying to ascertain whether any cultural impediments exist in relation to the enjoyment of their rights.

\subsection{Culture/Custom}

Culture is said to be the result of cultivation: a type of civilization. Custom on the other hand is defined a usage or practice of the people which by common adoption and acquiescence and by long and unvarying habit has become compulsory and has acquired the force of a law with respect to the place or subject matter to which it relates (Grener, 2009).

Customary or cultural practices are, therefore, rules of conduct established by usage or continuous practice over a long time. Oshorne C. J. in Lewis v. Bankole (1969) stated about customary law that one of the most striking features of West African native custom is its flexibility; it appears to have been always subject to motives of expediency and it shows unquestionable adaptability to altered circumstances without entirely losing its character.

Thus, custom is dynamic and not static. It is subject to change, particularly over a long period of time. There exist such customary practices in different parts of Nigeria, some of which have evolved into customary law, and are enforced as such by the existing authorities/ruling bodies. Some of these practices have been written down as laws, but most of them are largely unwritten but have the force of law. They are accepted by the communities concerned and are applied in some cases ruthlessly. Some of them do not even pass the repugnancy test, and as such are contrary to known principles.

\subsection{Rights of Women in Nigeria}

The constitution of the Federal Republic of Nigeria 1999 recognizes a wide range of rights for Nigerian citizens, be they male or female. Chapter II of the said Constitution spells out the fundamental objectives and directive principle of state policy and thus can be said to contain secondary rights of Nigerian citizens. Section 15(5), states that accordingly, national integration shall be actively encouraged, whilst discrimination on the grounds of place of origin, sex shall be prohibited.

According to section 17(2), in furtherance of the social order-(a) every citizen shall have equality of rights, obligations and opportunities before the law. As far as the directive principle of state policy is concerned, there is no difference whatsoever between a man and a woman. Both are to be treated equally as citizens of Nigeria without any discrimination.

The other range of rights principally primary rights, which the women enjoy equally with the men folk under the Constitution, are contained in Chapter IV of the 1999 constitution. They include the following: the right to life; right to dignity of human person; right to personal liberty; right to fair hearing; right to private and family life; right to freedom of though, conscience and religion; right to freedom of expression and the press; right to peaceful assembly and association; right to freedom of movement; right to freedom from discrimination; right to acquire and own immovable property anywhere in Nigeria.

Some ratified Conventions also touch on the rights of women and the child. As regards women generally, for example, there is the Convention on the Elimination of all Forms of Discrimination against Women (CEDAW, 1979), ratified by Nigeria in December 1991. The Universal Declaration of Human Rights (UDHR) adopted in 1948, the African Charter on Human and Peoples Rights in 1986, ratified and domesticated by Nigeria and the Convention on the Rights of the Child adopted in 1989 and ratified by Nigeria in 1992, and most importantly the Protocol to the African Charter on the Rights of Women in Africa, 2003.

As for the African Charter on Human and Peoples Rights, Article 2 thereof states that every individual shall be entitled to the enjoyment of the rights and freedoms recognized and guaranteed in the present charter without distinction of any kind such as sex. Article 5 provides that every individual shall have the right to the respect of the dignity inherent in a human being and to the recognition of his legal status. All forms of exploitation and 
degradation of man particularly slavery, slave trade, torture, cruel, inhuman or degrading punishment and treatment shall be prohibited.

It is thus clear from the foregoing that women in Nigeria enjoy the same status as men in Nigeria in the eyes of existing laws. Discriminatory practices are prohibited. However, women do not enjoy in full their rights as spelt out particularly in the 1999 Constitution or in previous Nigerian Constitutions. One of the impediments to the enjoyment of these rights is cultural practices which we now turn to consider.

\section{Cultural Practices}

\subsection{Sex as a Source of Inequality}

Many people hold the opinion that women in the family are egalitarian whilst others like Osita E. (1984: 142) feel that they are subservient. In many communities in Nigeria, men often discriminate against women on the flimsy ground that women are merely women by nature. They are often not allowed into the presence of men especially when crucial family or community issues are being discussed. Labour or tasks are usually shared according to sex. Thus, there are certain tasks reserved for men, and women dare not engage in them. Amongst the ufia people of Benue State for instance, it is considered a taboo for women to be palm wine tappers, rubber tappers, hunters or fisher women. These vocations are exclusively for men. It is even a taboo for a woman to be seen climbing trees to pluck fruits, or cut down palm nuts. This practice extends even to the Igbo people of Eastern Nigeria (Olong, 2009).

Cultural discrimination against women merely on the ground on their sex has constituted a grave impediment to the woman's right as foremost a human being that breathes the same air as men, and that has the ability to think and do things as much as the average man can. Women are looked upon in many traditional societies as weak persons who must be protected at all times, and as persons who cannot fend for themselves, without the guidance of men.

These perceptions of women by men have made the average woman particularly in many cultural settings in Nigeria to look upon men as Lords, and have caused them to develop inferiority complexes to their detriment.

\subsection{Inheritance of Women by Their Deceased Husbands' Relations}

In some communities in Nigeria, the death of a wife of a customary marriage automatically brings the marriage to an end. However, where it is the husband that dies, the marriage does not come to and end, the wife is inherited within the family. Thus, the woman is shared to any of the husband's brothers or relations and is expected to continue to perform her matrimonial roles to him whether she likes it or not. Even though this practice is gradually dying out because of the influence of religion, modernization, and the current scourge of HIV/AIDS, it is still going on in some communities in Nigeria even in the $3^{\text {rd }}$ millennium, Nigeria.

The unjust position of customary law is still being upheld by the courts. The Court of Appeal in the case of Ogunkoya v. Omo Ogunkoya (1988: 6) opined that the wives left are regarded as chattel that are inheritance by other members of the family (in Yoruba sense) of the deceased under certain conditions.

Where a widow opts to remain with the husband's family without remarrying anybody, probably to look after her children, should she be pregnant, the issue will be deemed to belong to her late husband. The woman does not have a say whatsoever in the matter, her humanity and feelings are completely ignored. This is of course unfair to both her and the natural father. It is against the principles of natural justice. We are of the view that passing on of a woman by way of inheritance from her late husband to any of her brother-in-laws is not only debasing, but a grave violation of her right to human dignity. In modern times, where emphasis is on the equality of spouses and the dignity of the human being, women should not be items of inheritance as if they are goods or property.

\subsection{Widows Succession Rights under Customary Law}

There are as many varieties of customary law in relation to succession rights of widows as there are ethnic groups in Nigeria. When a man subject to native law and custom dies intestate without contracting a monogamous marriage under the Marriage Act, his estate is regulated by the customary rules of intestate succession.

One rule of customary law which almost all the traditional Nigerian societies are unanimous about is that the widow has be place in the customary law of intestate succession, in the sense that she can never inherit from her husband if he dies intestate. Times without number, many widows have been driven out of their matrimonial homes with their late husband's properties including furniture and bedding seized by overzealous brothers-in-law and in the process completely disinheriting the widows. 
Justice James Ogebe (1988: 12) referred to a sad case that took place in a small village near Zaria. A young woman; Hausa non-Muslim married under customary law, unfortunately her husband died in a motor accident. Her grief was great, but her sorrow increased when her husband's father and two uncles came a week later and took all her husband's father and two uncles came a week later and took all her husband's clothes and the furniture in the husband's house. She and her two children under three years old were left with nothing. A month later, they returned, and took her oldest child leaving her with only the baby who was too young to leave her. She had no means of support and had no protection from the law because she had been married under customary law.

In Suberu v.Summonu (1957) Jibowu F. J. stated that it was a well settled rule of native law and custom of the Yoruba people that a wife could not inherit her husband's property since her herself is like a chattel, to be inherited by a relative of her husband". Similarly, in Sogunro-Davies v. Sogunro-Davies (1929), Beckley J. was of the view that a wife was deprived of inheritance rights in her deceased husband's estate because in intestacy under the native law and custom, the devolution of property follows the blood. Therefore, a wife or widow, not being of the blood, has no claim to any cause.

In Niezieanya v. Okagbue (1961) the woman's husband by name Ephraim died, survived by his wife Mary and a daughter. Mary took possession of his property consisting of a piece of lan and a house. She collected rents without accounting to anyone. Her efforts greatly enhanced the value of the property. On her death she bequeathed his property to certain beneficiaries whose rights were challenged by a relation of Ephraim. In an action brought by the beneficiaries to confirm their rights, Reynold J. was of the view that "this action must fail on the grounds that by native law and custom, possession by a widow of land can never be adverse to the right of her husband's family so as to enable her to acquire an absolute right of possession of it against the family".

The above position was also affirmed in Oshilaja v. Oshilaja (1972) where Adesanya J. noted that the customary law that a widow cannot inherit her deceased husband's property has become so notorious by frequent proof in the courts that it has become judicially noticeable.

A widow is, however, not entirely without customary rights in her late husband's estate. She has a legal right to retain the use and possession of the matrimonial home subject to good behavior. She is also entitled to farm in her deceased husband's farmland even if she has no surviving children, or she could be allocated a communal land. Also land may be allocated to widows that have infant sons to hold on their behalf or trust for them.

\subsection{Bride Price and Dowry}

Bride price is the money; price a man or the groom pays to purchase his bride/wife. The payment is made to the father or guardian of the bride on her account in respect of her traditional marriage to the groom.

As Nwogugu (1990: 224) affirms that bride-price varies from area to area; some are low, while others are high. These days, people seriously object to high bride-price. Bride-price ordinarily affects the dignity of the human person as guaranteed under section 34 of the 1999 Constitution of the Republic of Nigeria. Invariably, a situation where a woman is regarded as an object or article in a commercial transaction does not enhance her right to dignity as a human being.

In some communities, the value of the woman is seen in the light of the quantity of cash and other items paid or given by the man in exchange for his bride. Imo State is known as area where high pride-price is still rampant. Great value is put on girls there, and a man who ventures to marry a girl from there after going through the rigors of being depleted of his financial resources is considered a real man. The resultant effect been that many girls are left unmarried and some of them quickly move into their boyfriends houses and start assuming matrimonial responsibilities pending when they would raise enough money to do the 'proper thing'.

In some communities, the value of woman after bride-price has been paid on her is the production of as many children as possible for her husband. If this does not happen, the woman is tagged a failed woman, and the marriage hardly lasts. The tendency is that the husband may demand the return of his money to him as money paid for a consideration that has failed.

\subsection{Divorce}

There are two institutionalized marriages in Nigeria that is marriage under customary law and marriage under the Nigerian Marriage Act. The later forbids the taking of another spouse while the first marriage subsists and the Act states rigorous procedure for obtaining a divorce and ancillary reliefs could be granted to either spouse depending on the facts. As for the former, marriage is potentially polygamous for men and so they are not restricted to any number of wives. Obtaining a divorce under customary law is by far easier and less cumbersome especially for the men. 
There are two ways in which a customary law marriage can be dissolved. These are the judicial and the non-judicial methods. Despite the existence of courts in most communities in Nigeria, many people do not resort to judicial process for the dissolution of customary law marriage. Abundant evidence indicates that the non-judicial process is mostly patronized.

In situations where a couple married under customary law goes through divorce, the woman is required to refund the bride-price paid on her, she is thus made to make a refund regardless of the number of years she and her husband had been married and the number of children they had have. Even when the woman has been married for forty or more years she would still be required to make the refund.

Again, upon the divorce, the children of the marriage in most cases unless if they are less than three years old, are required to be in the man's custody and those three years and below are required to join the man at say age five. The woman is not entitled to anything, no house, no furniture, no farms, nothing. She is just asked to leave her matrimonial house for wherever.

The customary practice in relation to divorce as practiced by many traditional communities is certainly repugnant to natural justice, equity and good conscience. The man in divorce situations under Native Law and Custom is never asked to leave the home for his wife and children, regardless of whether or not he is the one at fault either by way of having committed adultery, engaged in wife beating, et cetere. The woman is the one that bears the brunt of not only being asked to leave, but also to refund bride-price paid many years ago.

The customary practices as above stated are not only discriminatory against the Nigerian woman, but also violates her right as a woman. Her rights to property, to her children, to self-respect and dignity are taken away when she is asked to leave and surrender everything including children in the process.

\subsection{The Single Woman}

Most traditional societies frown at the single woman phenomenon. It is completely unacceptable to most communities for a lady to remain unmarried. The situation is even worse if the lady in question indicates that she is not ready to marry at all. She would be called all sorts of names (e.g. whore, prostitute) and would be looked upon with disdain by all. The fact that such a lady is prosperous in the work of her hands would be considered inconsequential situations where a woman has a child or children for a man or men and ends up living alone without a man she calls a husband is not different. She would have no place in the community.

The "single woman" is thus not tolerated in many traditional societies, the way "singlemen" are tolerated, but then this intolerance is contrary to the tenets of evolving human rights practices. A woman whether young or old should be free to decide for herself what she wants out of life, whether she wants to marry or not. Her decision to remain unmarried ought not to be a source of concern for the whole community she lives in, in so far as she is not in any way committing any criminal offence against anyone. She should be accepted and due recognition ought to be given to the positive contributions she makes to the community she lives irrespective of the fact that she had decided not to marry.

\subsection{Child and Forced Marriage}

In some Nigerian societies, particularly in the Northern parts, virginity at marriage is considered as absolutely essential. Girls are, therefore, married off forcefully at extremely young ages under customary law, frequently to men many years older than they are. For instance, a girl of 13 may be given out in marriage to a 56 years old man. These child-wives do not know how to run a home and do not even know how to take care of themselves. In addition, they are often wounded by adult sex with their so called husbands and are forced to bear children before their bodies are fully matured. The common side effect is the damage of their private parts leading to hospitalization for vesico viginal fistula (V.V.F), and damage of their other organs due to prolonged obstructed labour.

On the other hand, some young girls who though are of marriageable age, feel they are not ready for marriage but are sometimes married off without their consent under native law and custom by their parents to much older men or even young boys. The issue that arises in cases of this nature is that the 'consent' of the girl concerned is hardly obtained.

\subsection{Polygamy and Sexual Ethics}

There is hardly any community in Nigeria where polygamy; the traditional practice of a man marrying more than one wife, is not practiced. Polygamy is still practiced in virtually all parts of Nigeria.

The direct opposite of polygamy is polyandry; the traditional practice of a women marrying more than one husband, whilst there is also the practice of Monogamy; the practice-not traditional-of one man marrying only 
one wife, and one woman marrying only one husband. The practice of monogamy is however not borne out of traditional practices unlike the traditional practices of polygamy and polyandry.

In Nigeria, the practice of polyandry is unheard of. It is a taboo for a woman to marry more than one husband at the same time. It is however an accepted norm in many communities for a man to marry more than one wife regardless of the feelings of the first wife. Thus, a man may choose to marry up to twenty-seven women as for example, late Fela Anikulapo Kuti while he was alive married 27 women at a go and was hailed by the society.

In a polygamous setting, the first wife is faced with all kinds of horrors as she is forced to put up with the antics of the other women and children as some women go to long lengths of visiting native doctors, poisoning, et cetera. Polygamy infringes on the woman's right to dignity and prohibits her from enjoying her marriage, particularly as she is forced to share her husband and home.

\subsection{Pregnancy/Child Bearing}

In many cultural settings in Nigeria, when a man marries a woman, the marriage must be blessed with the "fruit of the womb". It is thus unacceptable for a couple to be married for over one year without a child. The woman in such a situation would be blamed irrespective of whether it is the man who has failed to supply the necessary goods to enable her mix the same with her own goods to result in the birth of a baby. She is looked upon as an unproductive person and in some cases called names such as a witch or regarded wrongly as someone who has sold her womb.

Again, in situations where the woman gets pregnant and she later says that she wants an abortion with the excuse that she is unable to cope with keeping the pregnancy, members of the society would frown on such 'flimsy excuse' and decree that she must keep the pregnancy and deliver the child or children, if twins or triplets. Some women are known to have passed on in an attempt to forcefully keep pregnancies they themselves know they cannot cope with.

\subsection{Male Child Syndrome}

In many instances, after the wife has given birth to many girls-four to eight for example, the husband may insist that the wife should give birth to a baby boy without taking into account the heath implications. Reasons advanced by such men usually have to do with the question of cultural inheritance of his properties and the keeping or preserving of the family name. The girls are seen as chattels to be disposed of other men when they are matured to marry.

Some women who have had several caesarian operations that have resulted in these four to eight girls are made to still go through the agony of taking the risk of going through one more pregnancy and delivery in the vain hope that this time around it would be a boy. This category of men and women, who are advocates of the male child syndrome, need liberation, as they are completely ignorant of the capabilities of the female child. It just does not matter whether a child is male or female, particularly as female children have been known in many cases to keep and preserve the family and its name after their fathers have passed. The concept of the male child as being the pillar of the family is a mere cultural conjecture which must be done away with.

\subsection{Female Circumcision}

Circumcision is otherwise referred to in relation to women as female genital mutilation. This is a cultural practice which involves the putting off of a woman's clitoris so as to prevent her from having sexual urges. The practice is carried out with the brief that the circumcised woman would not like sex or have a libido and as such would not flirt with other men while married. The age at which circumcision is carried out varies. Depending on the culture of a community concerned, the practice may be carried out on the female during infancy, childhood-as a rite of "passage to womanhood" or during an "initiation ceremony" at the time of marriage or during her first pregnancy.

In some communities in Nigeria circumcision is even performed on dead women. Crying for the dead, in this instance is prohibited until the corpse is circumcised and the usual traditional ceremonies performed. This cultural practice is common amongst some Ibo areas of Eastern Nigeria. Cases abound of women and young girls giving up the ghost post circumcision, particularly, when the operation is done the crude way, under unhygienic conditions using broken bottles, rusted razor blades or knives or any other blunt objects.

Apart from deaths, female circumcision imparts negatively on the psyche of a woman. It leaves her frustrated particularly in her real life even when lawfully married. It leaves her with a deep sense of loss of something which she would never regain as if part of her life has been terminated. 


\subsection{Violence against Women}

Violence against women which is also referred to as domestic violence is the physical assault of one member of the family (usually the woman) by another member of the family usually the man, that is where the victim and the perpetrator have some forms of personal relationship.

Beating of wives by men as a means of correcting them is widespread and common in many Nigerian communities. Reasons adduced to justify wife beating include, provocation resulting from insubordination, denial of sex, inability to take care of the home and the children, et cetera. These days, the younger women appear to be very bitter about incidences of beatings by men to the extent that increasingly it is becoming a regular ground for the dissolution of customary law marriage.

It is an accepted norm traditionally for a man to beat his wife or inflict whatever injuries on her for whatever reason. It is, however, a taboo for a woman to beat her husband, in ufia land, she would be brought before the Council of Elders, charged, found guilty and fined. Fines usually take the form of payment of a certain sum of money plus a big he-goat and a bottle of "Hot". In some cases women can be asked to pack out of their matrimonial homes.

Violence of any sort should not have any place in any marriage be it traditional or otherwise. The woman in particular is naturally not as physically strong as the man, and so physical contests should be ruled out of homes. Couples should be counseled on amicable ways of setting their differences whenever they arise.

\subsection{Burial/Funeral Rites}

In those days, an Oba of Benin or Ibo King or Chief was usually buried with several of his wives who were to minister to his needs in the world beyond. There is hardly nothing on record to show, however, that any man was ever buried along with his dead wife. Queen Amina of Zazzau who was buried with men seems the only known exception. In some of our village communities, whenever a man dies his wife is usually suspected and often accused knowledge of and/or complicity in his death. Such suspicion or accusation is never made when a wife dies.

In some communities, the wife would practically go through "hell" to prove her innocence. In some areas, she would be made to drink water used in washing the corpse of her deceased husband in an attempt to prove her innocence. A refusal to drink the water would be complete proof of her guilt thus many accused women go through the ordeal which may in the end affect their health. While a man dies, the surviving wife of wives are subjected to dehumanizing funeral rites. In some cultures, every hair on her body is clearly shaven, unfortunately by co-women, she is made to wear black clothes and confined to the recesses of an inner chamber and forbidden to see the light of day for some period prescribed by custom. She dares not complain.

On the other hand, when a wife dies, the surviving husband is not subjected to any of these sadistic and dehumanizing experiences. Instead, in some areas, to avoid the perceived fear that the spirit of the dead wife may return at night to share his bed with him, another woman is found to keep him company.

The various customary practices in relation to burial and funeral rites as they affect the rights of bereaved women ought to be stopped through laws and by enlightening the peoples in the various communities of their harmful effects.

\subsection{Capacity to Contract and Own Property}

The issue discussed here is in relation to the capacity of women to under customary law contract and own property while still married to their husbands. In many communities in Nigeria, the long standing custom that women do not and cannot acquire properties like land, fishing ponds, et cerera, in their own right still persists. They are devoid of such contractual capacity. In some areas of Ibo land, the contractual capacity of women is limited to the acquisition of moveable properties. This position has been criticized by Nwabueze (1974: 483) who is of the opinion that women have legal capacity to acquire and dispose of any form of property acquired by them without any restraint.

The issue, however, dies not arise in the Yoruba custom where both the married and unmarried have full capacity to contract, acquire and dispose of all forms of property including land. In Igboland, women lack capacity to negotiate for any allocation of communal/family land for residential, commercial or any other purpose. There are local variations to this law for example in Aba, a widow might be allocated a communal land if she has no male issue. In some other local areas, they are allocated the land for farming purposes alone. Unmarried and divorced women as well as widows whose bribe price has been repaid are not entitled to allocation of communal lands except in some areas. 
It is the customary law that a married woman may acquire immovable and moveable property but has no personal right to acquire landed; immovable, property unless through the husband. A married woman also is forbidden from disposing her property whether moveable or immoveable without the consent of her husband.

It is clear from the general customs of people in Nigeria that a man does not require the consent of his wife or wives to acquire property whether moveable or immoveable. The man too does not need her or their consent before he can dispose of any property he acquired while married. It does not make any difference that he acquired such property with her or their help. This same man is also not bound by customary law to pay his wife's debt, even if it is accumulated by her in the course of acquiring the property which she cannot now dispose of without his consent, in order to pay her debt.

\subsection{Participation in Public Life and the Decision-making Process}

Women, whether married or unmarried, are usually not allowed to participate in any form of deliberations in the village arising from public interest, such matters are considered to be far above their understanding and scope. They are not usually even invited for such public meetings, and their participating in the ensuing debates does not even arise.

In Iboland, the woman's voice is excluded from such gatherings. She may be seen but not heard. Worse still is the position in the far Northern part of Nigeria where the woman must not be seen or heard. She has no say whatsoever in matters relating to the affairs of the community.

Generally, decisions affecting the entire community and even decisions affecting an extended family are taken by the men alone. Whether such decisions are sound or not is immaterial to the men. Women are, therefore, precluded from exercising their right to freedom of speech and association. Again, women cannot meet or hold meetings to decide on issues pertaining to entire community or their extended families. In situation where they do meet and reach decisions, such decisions no matter how sound or far reaching to the benefit of the community extended family are usually considered by the men as null and void.

The culture of excluding women from participating in public life and the decision making process is discriminatory against women and impedes their various rights as co-equals with men as human beings and ought to be discouraged. Some cultures in Nigeria see the woman as a being who is expected to serve the man in every way imaginable, she is thus the slave that cooks for him, washes his clothes, cleans the house, works in the farms, satisfies his sexual urges, etc.

Some other beliefs that are still prevalent include: education and training, mode of dressing and breadwinner status.

\section{Traditional Belifes}

\subsection{Educational and Training}

It is generally believed in some communities in Nigeria that money spent on educating or training a girl or woman is money wasted. Thus, emphasis is placed more on the education or training of boys or men. The inherent fear is that if a woman is educated, she ends up overthrowing the man (be it her elder brother, father or husband). She would tend to be more enlightened and have a higher place in the scheme of things. In places like Kano, Sokoto, Borno and some other parts of the Northern parts of Nigeria, education is not the lot of the 'girl' child instead most times they are hurriedly married off at tender ages.

\subsection{Mode of Dressing}

Culture has developed in almost all communities in Nigeria a dress code for women. They are considered responsible and homely when they tie wrappers and head ties. A smart looking woman in jeans trousers and tee-shirt is seen to be challenging a man whilst a woman in a short mini skirt is a whore and a devil. Meanwhile, the men are free to tie wrappers like the women (in Rivers, Delta States) and wear flowing gowns (in the Northern States) like women and it would not matter at all.

\subsection{Bread Winner Status}

It is generally believed that the man as the "head of the home" must be the breadwinner. Thus, a situation where a woman earns far more than the husband is unacceptable to many. The fear is that the woman would soon take over and start ruling the home. To this end, many men would do everything possible to deflate their wives moving businesses and discourage them from taking up higher paid employment. 


\section{Recommendations and Conclusions}

There are lots of similarities in the cultural practices among the various ethnic groups in Nigeria. As it is, women in Nigeria are deprived of almost all the rights enshrined in Chapter IV of the 1999 Constitution. There is, therefore, need to put in place structures to implement the enjoyment of these rights by the women in the same measures as enjoyed by the men. Such structures must of necessity include laws to be made by the various Houses of Assembly, the break down the existing cultural impediments.

Some laws in Nigeria seem to acknowledge the impact of culture or customs on women, and makes provisions which seemingly protect women, but in reality take away their rights as human beings. Section 141 of the Criminal Procedure Code is an example of such law and it provides that no court shall take cognizance of any offence falling under Chapter XXI or Chapter XXIII of the Penal Code or under Sections 383 to 386 aggrieved by such offence, but where the person so aggrieved is a woman who according to the customs and manners of the country ought not to be compelled to appear in public or where such person is under the age of eighteen or is and idiot or lunatic or is from sickness or infirmity unable to make a complaint, some other persons may with leave of the court, make a complaint on his or her behalf.

From the foregoing provision, it is crystal that a woman under most customs in Nigeria cannot present a complaint under section. 141 of the Criminal Procedure Code and is treated the same way as idiots, children or lunatics. Again, under section 142 of the Criminal Procedure Code, a woman has no right to make a complaint in relation to offences under section 387, 388 and 389 of the Penal Code. Such complaints must be made either by her husband, father or a male guardian. These therefore impede the rights of women to present complaints in person under S. 141 \& 142 of the Criminal Procedure Code, just as men would. A change in cultural practice would necessarily influence a change of the law as it presently is.

Judges on the other hand must be prepared to interpret the Constitution of Nigeria, 1999 and other relevant laws fairly and enter judgments that are fair and in accord with all known rules and principles of natural justice. Male judges in this wise should disabuse themselves of bias against women, and see them as human beings whose rights are in dire need of protection. They should also join in guarding woman rights jealously even if it means changing by precedent outdated customs that do not pass repugnancy tests.

Women too, apart from fighting for women liberation generally, should individually liberate their minds and have a clear vision of their ultimate objective role in the society and seriously work for it attainment. They should not be seen to be aiding the men in further impeding the enjoyment of rights by their fellow women by the use of culture. They should instead help to educate or inform the men folk of the need to do away with several cultural practices, which are discriminatory against women and prevent them from achieving whatever they want to achieve for the good and general wellbeing of the society at large.

Unfortunately, though in the third millennium, Nigeria, women well-being are rather faring worst. In most cases, legislation are yet to be promulgated and schemes put in place to enhance women rights and equal opportunities, even if it means the entrenchment of an affirmative action. Rather part of the legislation being promulgated is the Nudity Bill, which cannot seem to earn enough opprobrium and draw the most appalling derision amongst civilized societies.

\section{References}

Akande, J. O. (1979). Law and Customs Affecting Women's Status in Nigeria. Lagos: International Federation of Women Lawyer.

Eliot's, T. S. (2009). Notes Towards a Definition of Culture. Retrieved from www.applet-magic.com/cultureliot.htm

Higgins, T. E. (1990). Anti Essentialism Relativism \& Human Rights. Women's Law Journal.

Ifeyinwa, I. (1996). Women The Evolution of The Nigerian Constitutions and Political System/Order Since Independence (1960-1990's). Dartmenth Colelge Henover, New Hansphire May 15, 1996 at the Institute of African Studies.

Jadesola, A. (2005). The President (unreported suit no. FHC/ABJ/M/144/2005).

Ngangah, C. (1998). The Politics of Human Rights: A view from the Third World. Kaduna: Klamidas Communications Ltd,

Nwabueze, B. O. (1974). Nigerian Land Law. Enugu: Nwamite Publisers Ltd

Nwogugu, F. I. (1990). Family Law in Nigeria. Ibadan: N.E.D. 
Ogebe, J. (1988). Marriage in Nigeria: The legal Aspect. Jos: Challenge Publications

Omoso, C. I. (2009). Women in Nigeria: Religion, Culture, and the AIDS Pandemic. Retrieved August 2, 2009, from www.iheu.org/node/979

Osita, E. (1984). Human Rights in Africa: Some Selected Problems.

Oyelowo, O. (1982). 2 NWLR (PT. 56) at 239.

Romamy, C. (1993). Women as Aliens: A Feminist Critique of the Private/Public Distinction in International Human Rights Law. Harvard Human Right.

State, A. G. (1971). ALL NLR508.

The Nation Newspaper of March 9, 2009. 